\title{
卷而の 日策
}

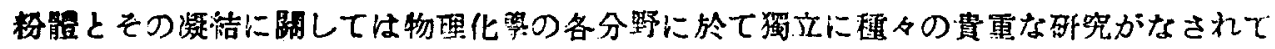

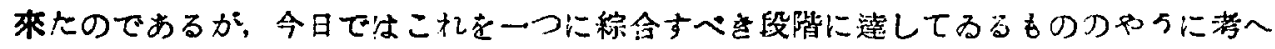
られる。又近來項に盛んになりつつある粉末治金にはこれらの物理化等つ裹附が必要で あるこれ本誌が企てられてゆえんである。.

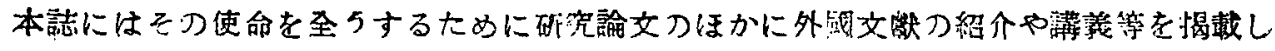

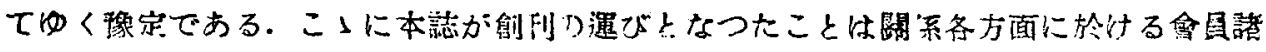

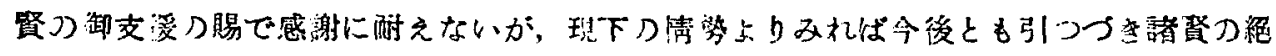

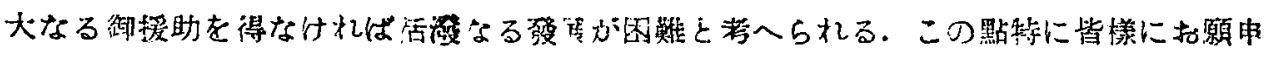

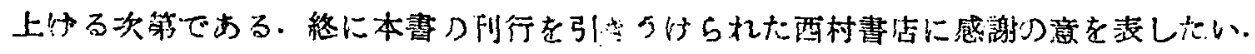
世話人つ一人として

(岩 瀨 悀

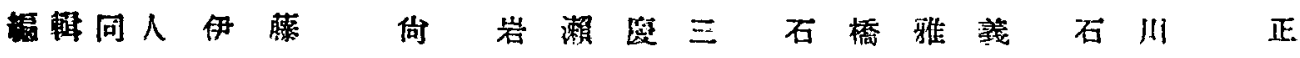

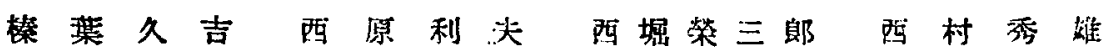

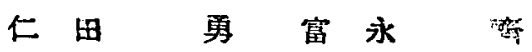
小川芳 樹同村俊应

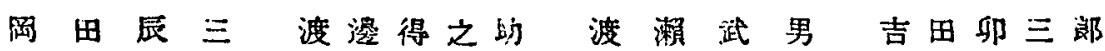

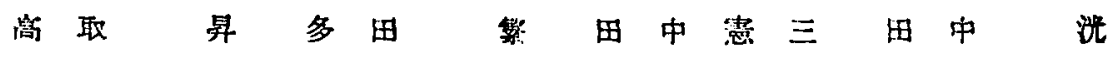

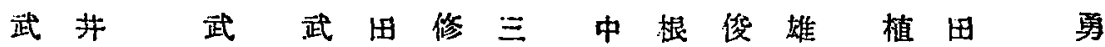

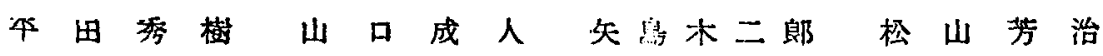

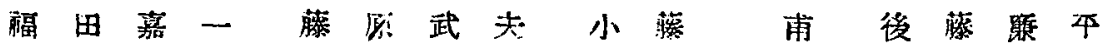
小平再江. 塚保阿部清有任徽彌

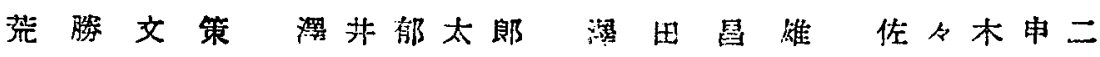

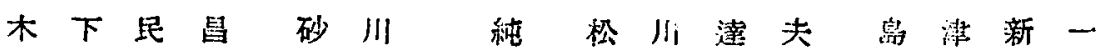

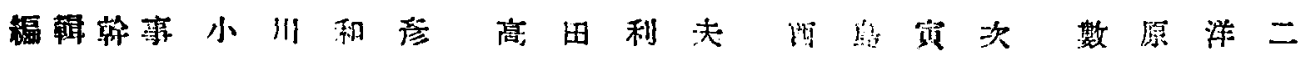
II畸元婎松村源太郎时代仁

庶称會計係 飯由学

第2 號队容

ii! $几$ 成人

石 $: 1$ 正椋末五郎

们正小椋和五郎

阙辰三小久保术堆

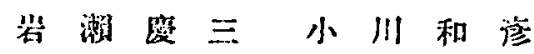

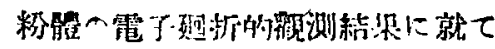

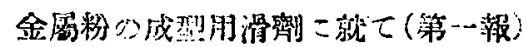

(第二频)

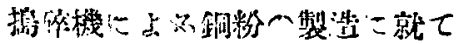

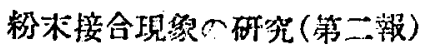

外海外抄鉎彔 